\title{
Marketing Accountability: Defining Expectations and Measuring Outcomes
}

\author{
David W. Stewart* \\ Department of Marketing and Business Law, 319 Hilton Business Center, Loyola Marymount University, \\ Los Angeles, USA \\ Email: david.stewart@lmu.edu
}

Received 25 April 2014; revised 1 June 2014; accepted 20 June 2014

Copyright (C) 2014 by author and Scientific Research Publishing Inc.

This work is licensed under the Creative Commons Attribution International License (CC BY).

http://creativecommons.org/licenses/by/4.0/

c) (i) Open Access

\begin{abstract}
This paper calls for work that focuses on the relationships of marketing activities and outcomes and measures of the financial performance of the firm. More specifically, the paper suggests the need to link marketing outcomes to the cash flow of the firm and the business model that generates the cash flow. The paper also calls for greater alignment of measures of marketing accountability with expectations and responsibilities of the marketing organization.
\end{abstract}

\section{Keywords}

Accountability, Marketing, Cash Flow, Business Models

\section{Introduction}

Marketing has long been a mysterious black hole in many organizations. There is few debates on if making the sale, building the brand and satisfying the customer are important to the firm and its success. However, how marketing does these things and what financial return can be attributed to marketing and its varied activities are poorly understood, even by many marketers. There are two reasons for this. Both deserve greater attention from scholars and practicing managers. The first of these reasons is that marketing contains many different things. The expectations of marketing vary from firm to firm and marketing is not defined by the same activities across firms. The second reason is that most firms are unable to tie marketing activities and outcomes to the financial performance of the firm. In this note, I explore these two issues and suggest areas where research can make a contribution to both the discipline and practice of marketing.

Landry, Tipping \& Dixon [1] of consulting firm Booz Allen Hamilton identify six different types of market-

*David W. Stewart is President's Professor of Marketing and Law at Loyola Marymount University and the current editor of the Journal of Public Policy and Marketing. He is a past editor of both the Journal of Marketing and the Journal of the Academy of Marketing Science. 
ing organizations: 1) growth champion, 2) senior counselor, 3) brand foreman, 4) growth facilitator, 5) best practices advisor and 6) service provider. These six types of marketing organizations differ with respect to their scope of responsibility, decision rights, capabilities, and organizational linkages [1]. These different types of marketers also differ with respect to what the organization expects of them, ranging from just performing specific tasks, like scheduling advertising, to providing advice to others, to strategic activities such as facilitating growth and managing branding activities. Most organizations gravitate toward one type of organization or another. There is no best organization and certainly not a best organization that has been identified by empirical research. Marketing organizations are simply different from organization to organization but their relative effectiveness is certainly a relevant research question.

The reason that this typology is important is because it has implications for how the marketing function should be evaluated within an organization. If marketing is merely a service provider that implements the decisions of others, the metrics of its performance should be very different from a marketing organization that is charged with the strategic task for driving growth. It is simply not possible to evaluate the performance of a function unless and until the scope of activities have been identified. "Marketing" is not what must be evaluated. Rather, it is marketing and its role as defined by the organization.

The definition of the marketing function within an organization is directly linked to the second reason firms are unable to evaluate marketing - the inability to link marketing activities and outcomes to the financial performance of the firm. Marketing has no shortage of measures but these measures are seldom linked to financial performance. Measures of awareness, band image, and customer satisfaction, among others are useful but do not indicate marketing contributes to the bottom line. Even such "hard" measures as sales volume and market share are not helpful unless they are linked to financial performance. Both sales and market share can increase even as revenues decline. Further complicating the evaluation process is the well recognized but poorly understood fact that marketing activities can create both immediate and long-lasting outcomes in the market.

For marketing, as for business as a whole, cash flow is the ultimate metric. Indeed, some have called for defining the objectives of marketing in terms of the identification and development of sources of cash flow [2]-[4]. Cash flow is the primary financial metric of the firm. It is a measure that is consistent across markets, products, customers, and activities. There are a very small number of drivers of cash flow. Cash is obtained from a source (customer acquisition and retention, share of wallet within a category, or share of wallet across categories). Cash is also produced through a business model (margins, velocity, or leverage).

The long established DuPont model [5] [6] suggests that cash can also be obtained through emphasis on one or more of three basic business models: margins, velocity, or leverage. Margins are the profits made on each individual unit sold. Velocity, or turns, is the frequency with which products are sold. Even at a small margin, a firm may be very profitable if it can turn inventory very frequently. Finally, cash may be produced through leverage. That is, a firm may be able to take an asset that it already possesses and leverage it into new uses or new activities to produce additional return on that activity. A good example of leverage is a brand extension. The brand already exists; it does not need to be built, and can be extended into a new category.

As a first step in linking marketing activities to financial performance the firm can identify how marketing activities and outcomes are linked the three cash flow drivers. Note that the focus is not on "marketing" as a general discipline but on specific marketing activities. The is an emerging focus on developing a better understanding of marketing and its activities, the link of activities to financial performance and the broader relationship of marketing to successful business model. The work of the Marketing Accountability Standards Board (MASB, http://www.themasb.org) is a catalyst for this effort.

This paper has focused on marketing but there are other areas within business that are also poorly defined and lacking in explicit links to the financial performance and business model of the firm. Human resources is another area that is really a collection of activities that may vary widely across organizations. Indeed, most of the more costly activities that also contribute most for the value to the firm are still poorly understood. This is because the questions around these activities are hard questions and do not lend themselves to quick and simple solutions. It is comparatively easy to compute the optimal route between a point of supply and a point of distribution. It is not so easy to identify the long-term benefits of building a brand or increasing retail shelf presence. But, it is the investigation of hard problems that promises to deliver the greatest value to scholarship, to firms and their stakeholders and society at large.

As the Open Journal of Business and Management (OJBM) begins its life as an outlet for scholarship in business, I encourage you to join me in contributing to big issues and the understanding of difficult problems. 


\section{References}

[1] Landry, E., Tipping, A. and Dixon, B. (2005) Six Types of Marketing Organizations: Where Do You Fit in? Strategy + Business. http://www.strategy-business.com/article/rr00025?gko=489ba

[2] Young, R.A., Weiss, A.M. and Stewart, D.W. (2006) Marketing Champions: Practical Strategies for Improving Marketing's Power, Influence, and Business Impact. Wiley Interscience, New York.

[3] Stewart, D.W. (2006) Putting Financial Discipline in Marketing: A Call to Action. Corporate Finance Review, 10, 14-21.

[4] Stewart, D.W. (2008) Contributing to the Bottom Line: Marketing Productivity, Effectiveness and Accountability. Journal of Advertising Research, 48, 94-105. http://dx.doi.org/10.2501/S0021849908080112

[5] Blumenthal, R.G. (1998) Tis the Gift to Be Simple. DuPont's Framework for Financial Analysis. CFO, 14, 61-64.

[6] Hawawini, C. and Viallet, G. (2006) Finance for Executives: Managing for Value Creation. South-Western Publishing, Cincinnati. 
Scientific Research Publishing (SCIRP) is one of the largest Open Access journal publishers. It is currently publishing more than 200 open access, online, peer-reviewed journals covering a wide range of academic disciplines. SCIRP serves the worldwide academic communities and contributes to the progress and application of science with its publication.

Other selected journals from SCIRP are listed as below. Submit your manuscript to us via either submit@scirp.org or Online Submission Portal.
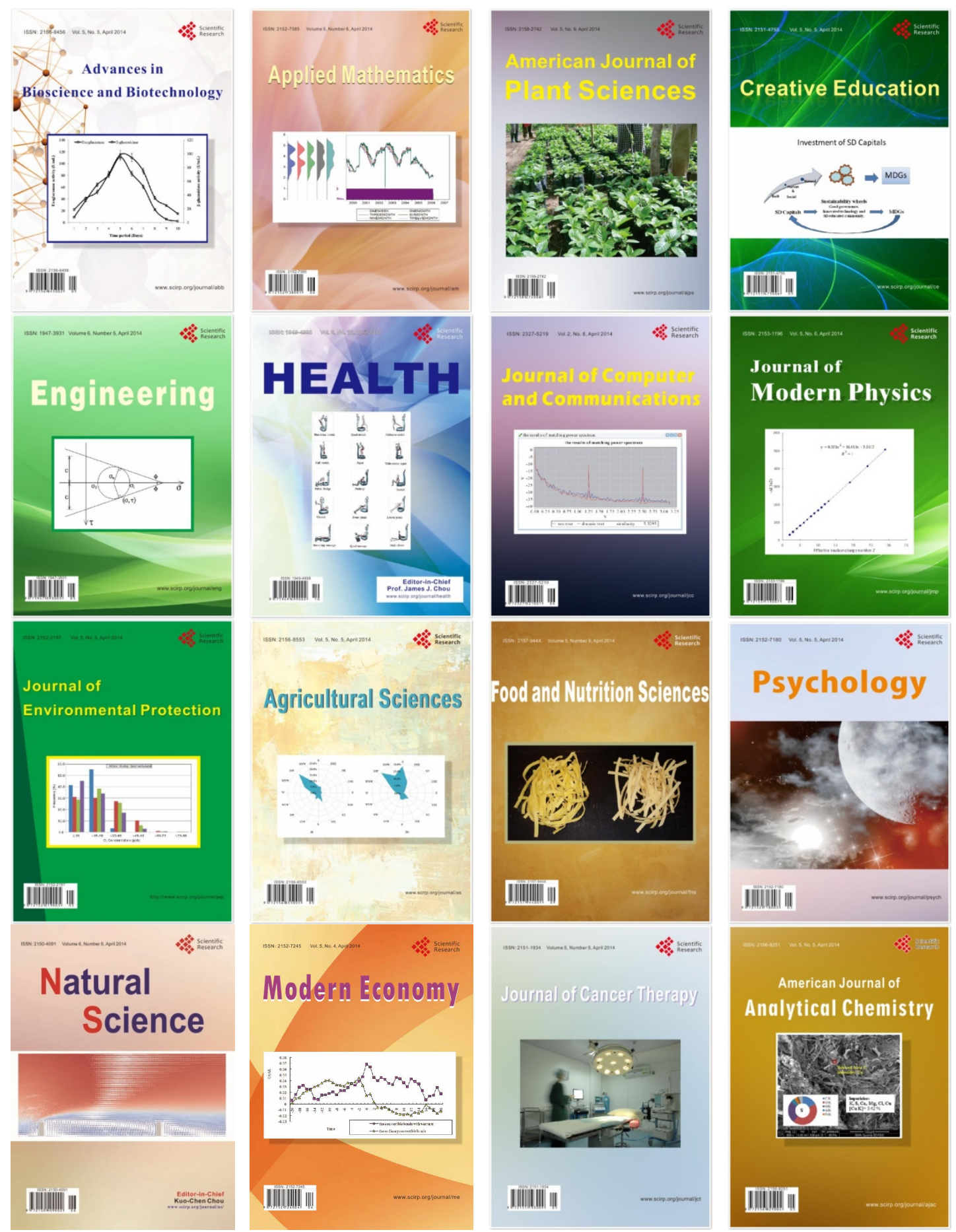